\title{
HERBAL MEDICINES USED BY BAPEDI TRADITIONAL HEALERS TO TREAT REPRODUCTIVE AILMENTS IN THE LIMPOPO PROVINCE, SOUTH AFRICA
}

\author{
S.S. Semenya ${ }^{1}$, A. Maroyi $^{1}{ }^{*}$, M.J. Potgieter ${ }^{1}$ and L.J.C. Erasmus ${ }^{2}$ \\ ${ }^{1}$ Departments of Biodiversity and ${ }^{2}$ Physiology and Environmental Health, School of Molecular and \\ Life Sciences, University of Limpopo, Private Bag X1106, Sovenga, 0727, South Africa. \\ Email: alfred.maroyi@ul.ac.za +2715 268 2933; Fax: +2715 2682184.
}

\begin{abstract}
The current study focussed on documenting the ethnobotanical knowledge of herbal medicines used by the Bapedi traditional healers to treat reproductive ailments in the Limpopo Province, South Africa. Fifty one healers from 17 municipalities covering Capricorn, Sekhukhune and Waterberg districts of the Limpopo Province were interviewed between January and July 2011. Semi-structured interviews, observations and guided field surveys with the healers were employed. Thirty-six medicinal plant species belonging to 35 genera and 20 families were documented. The most used species were Zanthoxylum humile (25.5\%), Catha edulis (21.6\%), Ozoroa sphaerocarpa (15.7\%), Hypoxis hemerocallidea (13.7\%), Hypoxis obtusa (11.7\%), Gomphocarpus fruticosus subsp. fruticosus and Gymnosporia senegalensis (9.8\% each). The dominant growth forms among the reported medicinal plants were herbs (39\%), followed by shrubs and trees with $33 \%$ and $28 \%$, respectively. The preferred plant parts were roots $(63.9 \%)$, followed by bark $(13.9 \%)$, whole plant $(11.1 \%)$, tubers (8.3\%), bulbs (5.6\%), fruits, leaves, stems and twigs (2.8\% each). The majority of the species were used to treat gender specific reproductive ailments; while a minority were used for treating reproductive ailments of both genders. Twenty-two species (61.1\%) are supported by reports of similar uses in other countries or have proven biological activity. This study illustrates that Bapedi traditional healers possess remarkable knowledge on medicinal plants used for treating and managing reproductive ailments.
\end{abstract}

Key words: Bapedi, ethnobotanical study, herbal medicines, reproductive ailments, traditional healers

\section{Introduction}

Traditional healers can be found in most societies (Cheikhyoussef et al., 2011). In sub-Saharan Africa, the ratio of traditional healers to the population is approximately 1:500, whilst western-trained medical doctors present a 1:40 000 ratio to the rest of the population (Richter, 2004). Kale (1995) and Setswe (1999) estimated that there were approximately 200 000 traditional healers practising in South Africa in 1995, compared to 25000 medical doctors. Traditional healers play an important role in their local community's tradition and primary health care system. Approximately $70-80 \%$ of the South African population still rely on traditional healers for day-to-day health care (UNAIDS, 2006), who prepare traditional remedies from as many as 700 indigenous plant species (Meyer and Afoloyan, 1995).

A large percentage of the population in developing countries uses traditional medicines. The reasons being their close proximity (Muthu et al., 2006), the high cost of western pharmaceuticals and health care, and because traditional medicines are more acceptable from a cultural and spiritual perspective (Cunningham, 1988). According to King and Homsy (1997), traditional healers provide client-centred, personalized health care that is culturally appropriate and tailored to meet the needs and expectations of the client by paying special attention to the social and spiritual concerns of the client. Msiska et al. (1997) noted that rural patients are more dependent on medicinal remedies from traditional healers for the treatment of reproductive ailments for a number of reasons, such as the lack of access to modern medical facilities and hesitancy to relate their illnesses to unfamiliar doctors. Research shows that a wide range of reproductive ailments from across the world are being treated by medicinal plants. These include for example, menstrual disorders, fertility problems, spermaturia and impotency in India (Hegde et al., 2007), cloudy urination in women, leucorrhoea in Bangladesh (Hossan et al, 2010), and womb problems, menstrual pain, and female complaints in Trinidad and Tobago (Lans, 2007). In South Africa, substantial numbers of women seek treatment from traditional health practitioners for a variety of complications and disorders associated with reproductive health (Bereda 2002). These include amongst others, menstrual disorders, abortion, antiabortifacient, contraception and breast problems (Steenkamp, 2003). In contrast, South African males consult traditional healers mostly for impotence (Rakuambo et al., 2006). For most ethnic groups in South Africa, this rich indigenous knowledge on medicinal species used to manage reproductive ailments is either poorly known or misunderstood. Thus a study was undertaken to document medicinal species used by the Bapedi traditional healers to treat reproductive ailments in the Limpopo Province of South Africa. 


\section{Materials and methods}

The study area

This study was conducted in 17 local municipalities of the Limpopo Province, covering three districts (Capricorn, Sekhukhune and Waterberg) (Figure 1, Table 1). The majority of people in the study area belong to the Bapedi ethnic group.

Figure 1. Study area: Capricorn, Sekhukhune and Waterberg districts, Limpopo Province, South Africa. A to Q designates the involved municipalities.

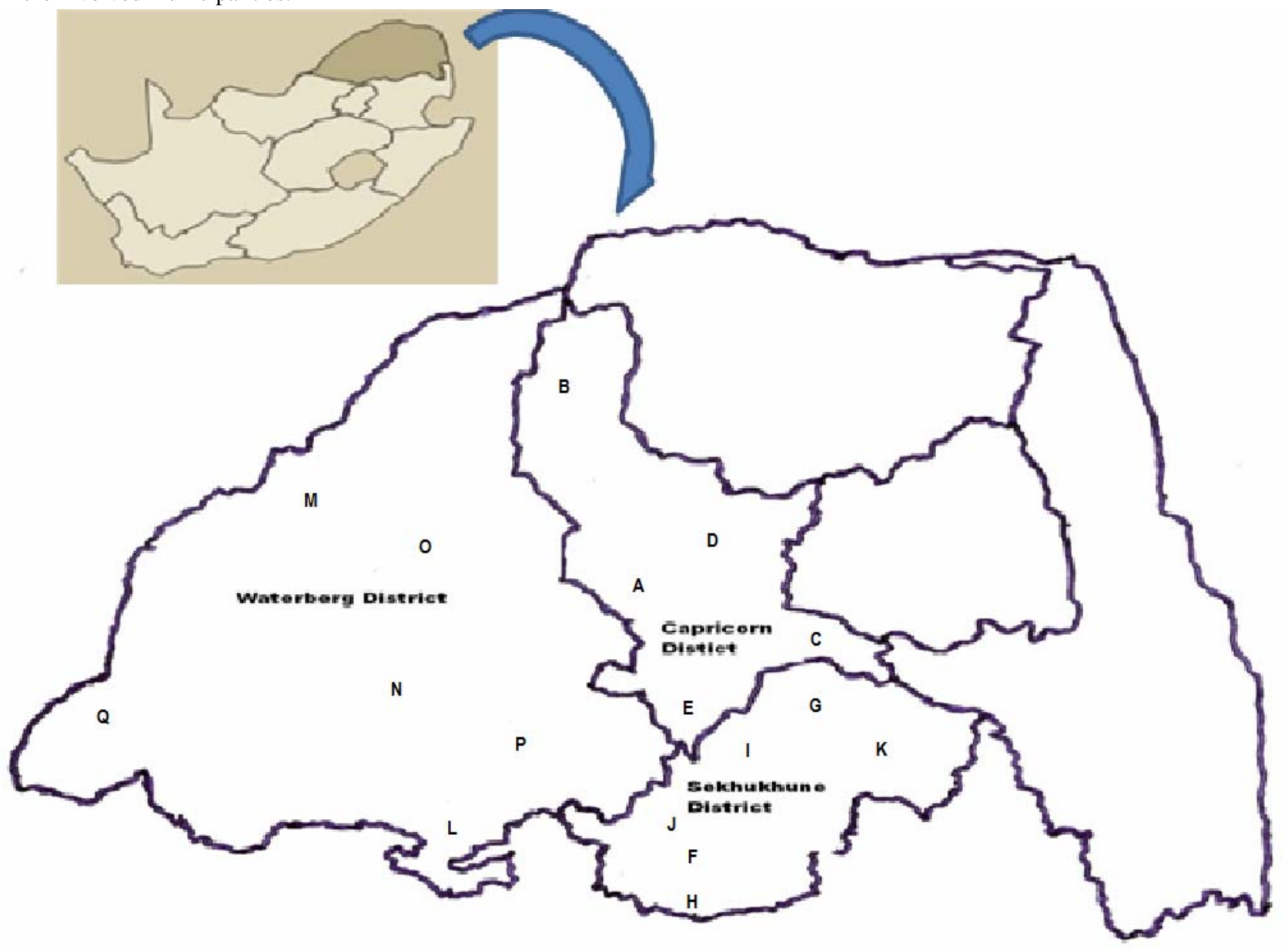

Table 1. Districts and local municipalities included in this study

Capricorn district

Aganang

Blouberg

Lepelle-Nkumpi

Molemole

Polokwane
Sekhukhune district

$\begin{array}{ll}\text { A } & \text { Elias Motsoaledi } \\ \text { B } & \text { Fetakgomo } \\ \text { C } & \text { Groblersdal } \\ \text { D } & \text { Makhuduthamaga } \\ \text { E } & \text { Marble Hall } \\ & \text { Tubatse }\end{array}$

Waterberg district

Bela-Bela

Lephalale

Modimolle

Mogalakwena

Mookgophong

Thabazimbi
L

M

$\mathrm{N}$

$\mathrm{O}$

$P$

Q

\section{Data collection}

A total of 51 Bapedi traditional healers were selected with the assistance of local administrators and elders. Data on medicinal plants used by them to treat reproductive ailments were collected from January 2011 to July 2011. Interviews and open-ended discussions with healers were conducted in Sepedi, the local language. Prior to interviews and any discussions on medicinal plants used to treat reproductive ailments, verbal informed consent was obtained from participating healers. The researchers also adhered to the ethical guidelines of the International Society of Ethnobiology. Information on plant names, plant part(s) used, methods of herbal preparation, administration, dosage and duration of treatments were documented. Based on ethnobotanical information provided by traditional healers, voucher specimens were collected and deposited at the Larry Leach Herbarium (UNIN), University of Limpopo. 


\section{Results and discussion \\ Medicinal plant diversity}

Bapedi traditional healers use 36 plant species to manage reproductive health problems (Table 2). These medicinal species are distributed among 35 genera and 20 families. The largest proportion of medicinal species collected belongs to the family Asteraceae (6 species), followed by Fabaceae (4 species); Celastraceae and Euphorbiaceae (3 species each); Anacardiaceae, Apocynaceae, Hyacinthaceae and Hypoxidaceae (2 species each). Other families were represented by a single species each. The dominance of the Asteraceae and Fabaceae, and to a lesser extent the Euphorbiaceae, probably relate to their large numbers of species. Thus it is not surprising that these families have also been recorded in ethnomedicinal inventories of different countries throughout Africa and Asia. For example, Kamatenesi-Mugisha and Oryem-Origa (2005) reported on the dominance of the Euphorbiaceae in the treatment of impotency in western Uganda. The Asteraceae and Euphorbiaceae were documented as dominant families in the treatment of reproductive ailments in Cameroon (Focho et al., 2009) and Ghana (Diame, 2010). Hossan et al. (2010) noted the dominance of the Fabaceae in the treatment of urinary tract infections and sexually transmitted diseases in Bangladesh.

Table 2: Plant species used for the treatment of reproductive ailments in the Limpopo Province. An asterisk $(*)$ indicates that the taxon is known or believed to be exotic to the Limpopo Province

Family, species name

Vernacular Habit Vouche

name

Amaryllidacea

Ammocharis
coranica (Ker

Gawl.) Herb

Anacardiaceae

Ozoroa

sphaerocarpa

R. \& A.Fern.

Sclerocary

birrea

(A.Rich.)

Hochst.

Apocynaceae

Ceropegia

purpurascens

K.Schum. ssp.

purpurascens

Gomphocarpu

$s$ fruticosus

(L.) Aiton f.

ssp. fruticosus

Asteraceae

*Artemisia

annua $\mathrm{L}$.

*Bidens

pilosa L.

onoko

Morula

Tree

SS 1

Bark

Part(s

Preparation

) used

administration

and

cito.

$\mathrm{s}(\%)$

ailn

Boiled for 10 minutes and extract taken orally thrice a day.

Pounded and 5 teaspoons taken orally with soft porridge thrice a day.

Boiled for 5-10 minutes and extract taken orally thrice a day.

15.7

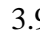

Monamela Herb SS 39 Root

Mosotsa

poo

atla

Mophodisa/

Mokolonya

ne

Brachylaena

discolor DC.

Mphahla

SS 31

Root/

Boiled for 5-20 minutes and extract taken orally thrice a day.

Callilepsis

Phelana

Herb

SS 62

Tuber

Boiled for 5 minutes and extract taken orally thrice a day.

Boiled for 20 minutes
Reproductive

Impotence

None found

Female
infertility

Female

infertility

Impotence;

low sperm

count

Other reported uses for reproductive ailments from literature

None found

Bilharziasis and heavy menstruation (Gelfand et al., 1985); Female infertility (Mabogo, 1990)

None found

Facilitate child-birth (Iwalewa et al., 2007; Watt and BreyerBrandwyk, 1962)

None found

Menstrual Menstrual disorder disorder (Mabogo, 1990); prostate disturbances (Tene et al., 2007); STDs (De Wet et al., 2012)

None found

Impotence (Seedat and Hitchcock, 1971); Induce fertility in woman (Debetto, 1978)

Period pains None found 
http://dx.doi.org/10.4314/ajtcam.v10i2.19

aspera Harv. hle

var. aspera

Kleinia Lekgabolo/ Herb SS 217 Root Macerated in warm

longiflora DC. Motlalamas wi

Caricaceae

*Carica

papaya $\mathrm{L}$.

Mophopho Tree SS 70

Root

teaspoons taken orally

with soft porridge thrice a day.

Fruit Squeezed juice from unripe fruit taken orally thrice a day.

Celastraceae

Catha edulis

(Vahl.) Endl.
Shrub SS 77

Root

Boiled for 5 minutes and extract taken orally thrice a day.
Elaeodendron transvaalense (Burtt Davy)

R.H.Archer

\section{Gymnosporia} senegalensis

(Lam.) Loes.

Cyperaceae

Cyperus

papyrus L.

Euphorbiaceae

*Chamaesyce

prostrata

(Aiton) Small

Euphorbia

ex Boiss.

* Jatropha

curcas L.

Sehlare

banna

Fabaceae

Elephantorrhi

za elephantina

(Burch.)

Skeels

Sesese

omo ingens E.Mey.
Monamane Tree SS 32

Mophato

Mohlaka

Herb

SS 97

Herb

SS 213

Mohlohlokg Tree

Mosehlana

Shrub

SS 100

Root

bark plant plant

SS 34 Stem
Root/ Combined with

Peltophorum africanum bark and boiled for 2030 minutes and taken orally thrice a day.

Root/ Boiled for 5-20 minutes leaf and extract taken orally

Whole Boiled for 5 minutes thrice a day.

Whole Boiled for 20 minutes and extract taken orally thrice a day.

Squeezed juice applied 5.8 topically after bathing.

Boiled for 5 minutes and extract taken orally thrice a day.

Boiled for 20 minutes and extract taken orally thrice a day.

3.9

2.0 thrice a day. and extract taken orally

21.6

Female

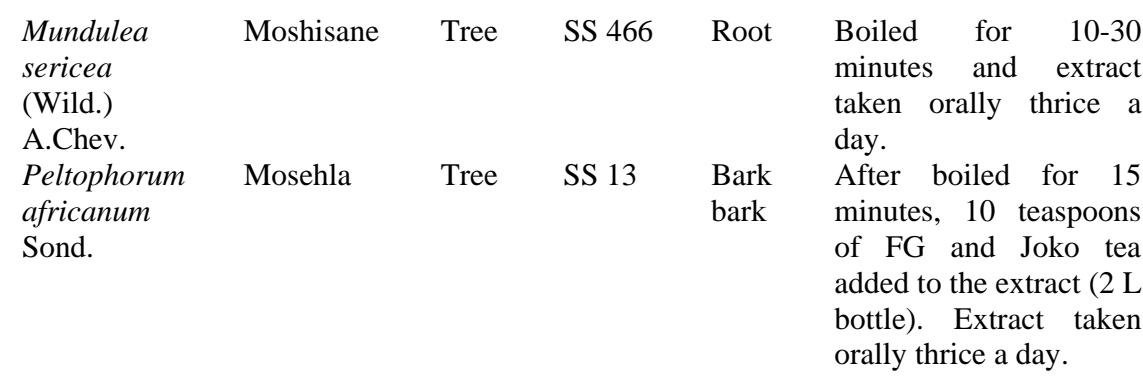

Impotence

infertility

Impotence

Menstrual

disorder

Womb

problem

Breast cancer

Impotence;

vaginal

candidiasis

Impotence

(2)

Fertility

(Cheikhyoussef et al., 2011)

Abortion (Morton, 1987); impotence (Kamatenesi-Mugisha and Oryem-Origa, 2005)

\section{Impotence}

(Kamatenesi-Mugisha and Oryem-Origa, 2005); infertility in men (Gelfand et al., 1985); urine retention (Mesfin et al., 2009) Herpes (Mabogo, 1990); HIV (Bessong et al., 2005)

None found

Facilitate birth (Cheikhyoussef et al., 2011)

Venereal complaints (Lans, 2007)

Gonorrhoea and stomach-ache during childbirth (Schmelzer, 2008)

Vaginal candidiasis (Diame, 2010)

Aphrodisiac, infertility in women and painful menstruation (Gelfand et al., 1985); syphilis (Gerstner, 1939; Jacot-Guillardmod, 1971)

Menstrua disorders Infertility (Gelfand et al., 1985)

Female infertility; post partum
Infertility in women and venereal diseases (Gelfand et al., 1985); STDs (De Wet et al., 2012; Samie et al., 2005); syphilis 


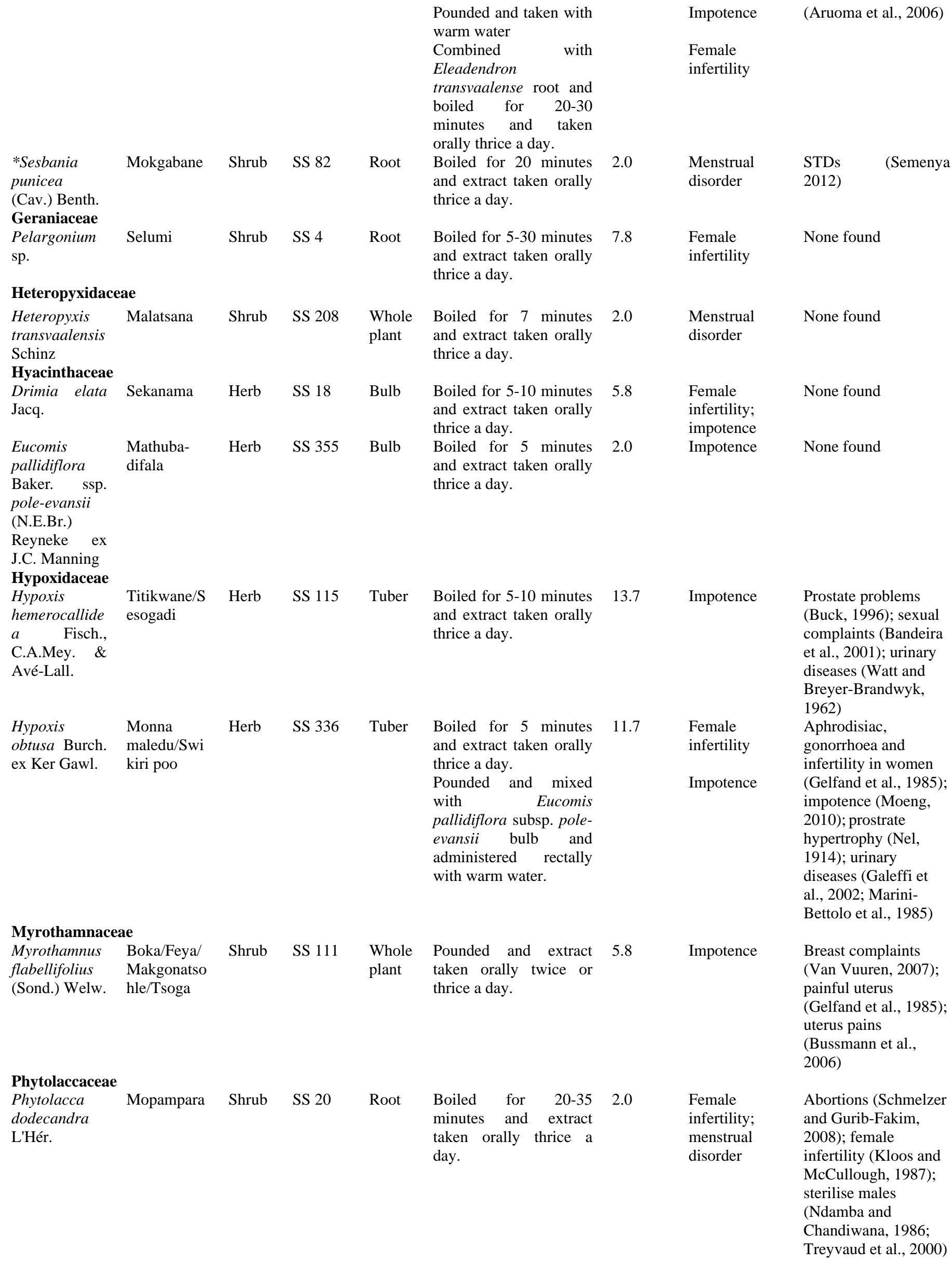


http://dx.doi.org/10.4314/ajtcam.v10i2.19

\section{Polygalaceae}

Securidaca

longepeduncul

Mopesu

Tree

SS 7

Root

ata Fresen.

\section{Rosaceae}

*Prunus

persica

Batsch

(L.)

persica

Rutaceae

Zanthoxylum

humile

Monokwane Shrub SS 19

(E.A.Bruce)

P.G.

Santalaceae

Osyris

lanceolata

Hochst.

Mphera

Shrub

SS 61

Root

Steud.

Solanaceae

*Capsicum

chinese L.

\author{
Pounded and mixed 2.0 Impotence \\ with Zanthoxylum \\ humile root and 5 \\ teaspoons taken with \\ soft porridge thrice a \\ day.
}

Pounded and 5-7
teaspoons taken with
soft porridge thrice a

day.

Root

Pounded and 5-10

teaspoons taken with

soft porridge thrice a

day.

Impotence
Boiled for 10-20

minutes and extract

taken orally thrice a

day.

$7.8 \quad$ Impotence;
menstrual
disorder

disorder

Root
Boiled for 15 minutes

and extract taken orally thrice a day.
Gonorrhoea (Jiofack et al., 2009); impotence

(Tshisikhawe, 2002); venereal diseases

(Bruschi et al., 2011)

Menstruation (Teng et al., 2011)

None found

Impotence (Muthee et al., 2011); menstrual disorders (Arnold and Gulimian, 1984; Mulaudzi et al., 2011); venereal diseases (Mulaudzi et al., 2011)
2.0
Period pains
None found

The most mentioned medicinal species were Zanthoxylum humile (25.5\%), Catha edulis (21.6\%), Ozoroa sphaerocarpa (15.7\%), Hypoxis hemerocallidea (13.7\%), Hypoxis obtusa (11.7\% each), as well as Gomphocarpus fruticosus subsp. fruticosus and Gymnosporia senegalensis ( $9.8 \%$ each). All of them are used to treat impotence. Bapedi traditional healers noted that male impotence is a prevalent health problem in the study area, which is in line with research by Kandeel et al. (2001) that showed impotence to be a global problem affecting the majority of men. To manage low sperm counts, Bapedi healers used 11 species that included Ammocharis coranica, Artemisia annua, Callilepsis laureola, Ceropegia purpurascens subsp. purpurascens, Elephantorrhiza elephantina, Eucomis pallidiflora subsp. pole-evansii, Myrothamnus flabellifolius, Ozoroa sphaerocarpa, Prunus persica var. persica, Securidaca longepedunculata and Zanthoxylum humile.

Fifteen species (41.7\%) are used by Bapedi traditional healers to treat female reproductive problems. These include: Bidens pilosa, Brachylaena discolor, Capsicum chinese, Chamaesyce prostrata, Cyperus papyrus, Elaeodendron transvaalense, Euphorbia ingens, Geigeria aspera var. aspera, Heteropyxis transvaalensis, Kleinia longiflora, Mundulea sericea, Pelargonium spp., Phytolacca dodecandra, Sesbania punicea and Sclerocarya birrea. The utilized species were mainly to treat female infertility. Female fertility is a dominant theme in the culture of black South Africans as it ensures preservation and propagation of the tribe (Veale et al., 1992), while the inability to conceive is regarded as a disgrace, as procreation is expected to follow marriage (Katsoulis, 2000). The above mentioned species were also used to a lesser extent in initiating abortion, and to manage breast cancer, menstrual disorders, period pains, vaginal candidiasis and womb problems. Only 6 medicinal species (16.6\%) were used to treat and manage both male and female reproductive problems; Carica papaya (impotence and abortion), Jatropha curcas (impotence and vaginal candidiasis), Osyris lanceolata (impotence and menstrual disorder), Peltophorum africanum (impotence and female infertility), as well as Drimia elata and Hypoxis obtusa (impotence and female infertility).

\section{Literature based proof of Bapedi traditional healers’ claims}

Twenty two (61.1\%) of the 36 species used by Bapedi traditional healers to treat reproductive ailments have been validated either by reports of similar uses elsewhere or through proven biological activity (Table 2). The therapeutic claims of the following plant species are well- supported in the literature: Bidens pilosa (De Wet et al., 2012; Mabogo, 1990; Tene et al., 2007), Callilepsis laureola (Debetto, 1978; Seedat and Hitchcock, 1971), Carica papaya (Kamatenesi-Mugisha and Oryem-Origa, 2005; Morton, 1987), Catha edulis (Gelfand et al., 1985; Kamatenesi-Mugisha and Oryem-Origa, 2005; Mesfin et al., 2009), Chamaesyce prostrata (Lans, 2007), Cyperus papyrus (Cheikhyoussef et al., 2011), Eleadendron transvaalense (Mabogo, 1990; Bessong et al., 2005), Elephantorrhiza elephantina (Gelfand et al., 1985; Gerstner, 1939; Jacot-Guillardmod, 1971), Euphorbia ingens (Schmelzer, 2008), Gomphocarpus fruticosus ssp. fruticosus (Iwalewa et al., 2007; Watt and Breyer-Brandwyk, 1962), Hypoxis hemerocallidea (Bandeira et al., 2001; Buck, 1996; Watt and BreyerBrandwyk, 1962), Hypoxis obtusa (Galeffi et al., 2002; Gelfand et al., 1985; Marini-Bettolo et al., 1985; Moeng and Potgieter, 2011; Nel, 1914), Jatropha curcas (Diame, 2010), Kleinia longiflora (Cheikhyoussef et al., 2011), Mundulea 
sericea ssp. sericea (Gelfand et al., 1985), Myrothamnus flabellifolius (Bussmann et al., 2006; Gelfand et al., 1985; Van Vuuren, 2007), Osyris lanceolata (Arnold and Gulimian, 1984; Mulaudzi et al., 2011; Mutheea et al., 2011), Peltophorum africanum (Aruoma et al., 2006; De Wet et al., 2012; Gelfand et al., 1985; Samie et al., 2005), Phytolacca dodecandra (Kloos and McCullough, 1987; Ndamba and Chandiwana, 1986; Schmelzer and Gurib-Fakim, 2008; Treyvaud et al., 2000), Prunus persica var. persica (Teng et al., 2011), Sesbania punicea (Semenya et al., 2012), Sclerocarya birrea (Gelfand et al., 1985; Mabogo, 1990) and Securidaca longepedunculata (Bruschi et al., 2011; Jiofack et al., 2009; Tshisikhawe, 2002).

Phytochemical and pharmaceutical studies have been done on some of the medicinal plant species documented in this study, examples include testing the efficacy of Securidaca longepedunculata as a potential remedy for sexual dysfunction (Rakuamboa et al., 2006; Sumalatha et al., 2010). Anti-fertility activities of Phytolacca dodecandra has been reported by Taniguchi et al. (1978) and Katende et al. (1995). Extract of Catha edulis at the dose of $100 \mathrm{mg} / \mathrm{kg}$ reduced mounting and intromission latencies, thereby enhancing sexual motivation or arousal in male rats after 15 days of treatment (Abdulwaheb et al., 2007). Adebivi et al. (2002) noted that unripe or semi-ripe Carica papaya fruit is unsafe in pregnancy and its consumption usually resulted in abortion. Furthermore, preliminary clinical research in a primate model demonstrated the potential contraceptive and abortifacient capability of Carica papaya (Lohiya et al., 2002). This study found that Carica papaya seeds have contraceptive effects in adult female langur monkeys, and possibly in adult female humans.

\section{Growth forms, plant parts used and method of herbal application}

An analysis of the medicinal species used by the Bapedi traditional healers to treat reproductive ailments, revealed that 28 species (77.8\%) are indigenous to the Limpopo Province, while 8 species $(22.2 \%)$ are exotics. Herbs constituted the largest proportion of growth forms (39\%), followed by shrubs and trees with $33 \%$ and $28 \%$, respectively. The plant parts mostly used to prepare herbal medicines were roots (63.9\%), followed by bark (13.9\%), whole plants (11.1\%), tubers (8.3\%), bulbs (5.6\%), fruits, leaves, stems and twigs (2.8\% each) (Figure 2). Results obtained in this study compares favourably with findings by Steenkamp (2003) who reported the widespread use of root and bark remedies by South African women for gynaecological complaints. Similar findings were reported by Hedge et al. (2007) who noted the extensive use of root and bark remedies for treating reproductive ailments in India.

Mono therapies based on preparations made from a single species were the most prevalent $(91.7 \%)$, and only $8.3 \%$ of reproductive health remedies were prepared from a combination of two or more species. This is in line with findings of Hegde et al. (2007) and Hossan et al. (2010) who found that traditional healers in India also prefer using a single species for herbal preparations to treat reproductive ailments. The preference for a single-based species extract is unknown at this stage and warrants further investigations. However, we postulate that it could be that the various species for multi therapies (2 or more species) might not always be available or that more effort and finances need to be expended to collect species for multi therapies, making it unattractive. In our study, plant remedies were often utilized in the form of extracts (72.5\%) and powder (20\%). Plant remedies were also made by maceration or squeezing (5\%). This involved the use of Euphorbia ingens stem sap or immature fruit of Carica papaya and root maceration of Kleinia longiflora. The majority (97.3\%) of the herbal remedies were administered orally three times a day until reproductive health ailments subsided. Stem sap of Euphorbia ingens was applied topically on an incision on breasts made by the traditional healer.

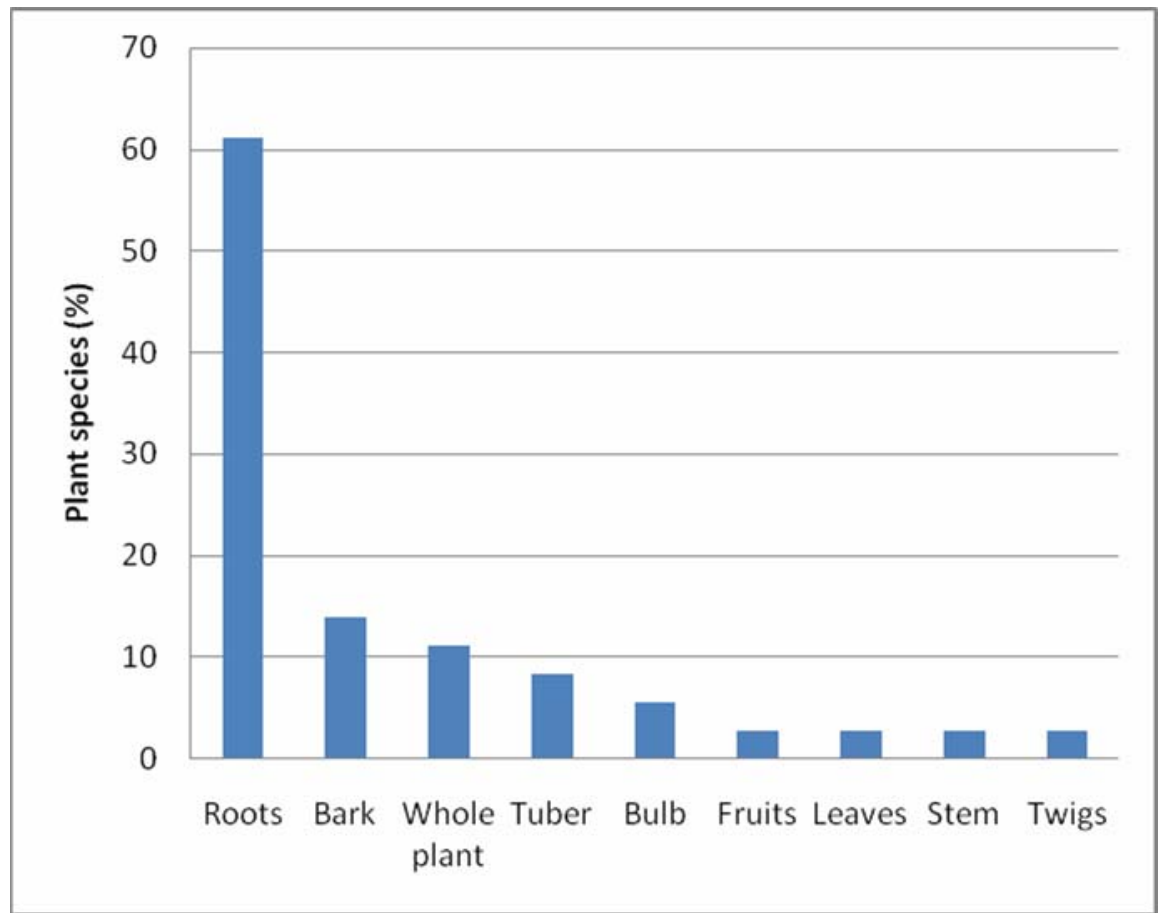

Figure 2. Plant parts used by Bapedi traditional healers to treat reproductive health ailments. 
http://dx.doi.org/10.4314/ajtcam.v10i2.19

\section{Conclusion}

This study shows that Bapedi traditional healers utilised a significant number of medicinal species to treat reproductive ailments. It is thus of paramount importance to verify the phytochemical safety and pharmaceutical efficacy of these herbal remedies. Since roots, bark and even whole plants are used, the risk of plant and species loss is high in the Limpopo Province of South Africa. This loss may inter alia lead to the disappearance of many traditional healers and ultimately cultural identity.

\section{References}

1. Abdulwaheb, M., Makonnen, E., Debella, A. and Abebe, D. (2007). Effect of Catha edulis Foresk (khat) extracts on male rat sexual behavior. J. Ethnopharmacol. 110: 250-256.

2. Adebiyi, A., Adaikan, P.G. and Prasad, R.N. (2002). Papaya (Carica papaya) consumption is unsafe in pregnancy: fact or fable? Scientific evaluation of a common belief in some parts of Asia using a rat model. Br. J. Nutr. 88: 199-203.

3. Arnold, H.J. and Gulumian., M. (1984). Pharmacopoeia of traditional medicine in Venda. J. Ethnopharmacol. 12: 35-74.

4. Aruoma, O.I., Colognato, R., Fontana, I., Gartlon, J., Migliore, L., Koike, K., Coecke, S., Lamy, E., Mersch-Sundermann, V., Laurenza, I., Benzi, L., Yoshino, F., Kobayashi, K. and Lee, M.C. (2006). Molecular effects of fermented papaya preparation on oxidative damage, MAP kinase activation and modulation of the benzo[a]pyrene mediated genotoxicity. Biofactors 26: 147-159.

5. Banderia, S.O., Gaspar, F. and Pagula, F.P. (2001). African ethnobotany and health care: Emphasis on Mozambique. Pharm. Biol. 39: 70-73.

6. Bereda, J.E. (2002). Traditional healing as a health care delivery in a transcultural society. M.Sc Dissertation. University of South Africa, South Africa.

7. Bessong, P.O., Obi, C.L., Andréola, M.L., Rojas, L.B., Pouységu, L., Igumbor, E., Meyer, J.J., Quideau, S. and Litvak, S. (2005). Evaluation of selected South African medicinal plants for inhibitory properties against human immunodeficiency Virus Type 1 reverse transcriptase and Integrase. J. Ethnopharmacol. 99: 83-91.

8. Bruschi, P., Morganti, M., Mancini, M. and Signorini, M.A. (2011). Traditional healers and laypeople: A qualitative and quantitative approach to local knowledge on medicinal plants in Muda (Mozambique). J. Ethnopharmacol. 138: 543-563.

9. $\quad$ Buck, A.C. (1996). Phytotherapy for the prostate. BJUI 78: 325-336.

10. Bussmann, R.W., Gilbreath, G.G., Solio, J., Lutura, M., Lutuluo, R., Kunguru, K., Wood, N. and Mathenge, S.G. (2006). Plant use of the Maasai of Sekenani Valley, Maasai Mara, Kenya. J. Ethnobiol. Ethnomed. 2: 22. doi: 10.1186/1746-4269-2-22.

11. Cheikhyoussef, A., Shapi, M., Matengu, K. and Ashekele, H.M. (2011). Ethnobotanical study of indigenous knowledge on medicinal plant use by traditional healers in Oshikoto region, Namibia. J. Ethnobiol. Ethnomed. 7: 10 doi:10.1186/1746-4269-710.

12. Cunningham, A.B. (1988). An investigation of the herbal medicine trade in Natal/KwaZulu. Investigational Report No 29. Institute of Natural Resources.

13. Debetto, P. (1978). Plants recently found to contain atractylosides. In: Santi, R. and Luciani, S. (eds), Atractyloside: Chemistry, biochemistry and toxicology, Piccini, Padova. Pp. 125-129.

14. De Wet, H., Nzama, V.N. and Van Vuuren, S.F. (2012). Medicinal plants used for the treatment of sexually transmitted infections by lay people in northern Maputaland, KwaZulu-Natal Province, South Africa. S. Afr. J. Bot. 78: 12-20.

15. Diame, G.L.A., 2010. Ethnobotany and ecological studies of plants used for reproductive health: a case study at Bia biosphere reserve in the western region of Ghana. Department of Environmental Science, University of Cape Coast, Ghana.

16. Focho, D.A., Nkeng, E.A.P., Lucha, C.F., Ndam, W.T. and Afegenui, A. (2009). Ethnobotanical survey of plants used to treat diseases of the reproductive system and preliminary phytochemical screening of some species of Malvaceae in Ndop Central Sub-division, Cameroon. J. Med. Plant Res. 3: 301-314.

17. Galeffi, C., Nicoletti, M., Palazzino, G. and Federici, E. (2002). Hypoxidaceae, a monocotyledons family source of norlignan glucosides with different biological activities. Trad. Med. Mat. Medica 1: 121-128.

18. Gelfand, M., Drummond, R.B., Mavi, S. and Ndemera, B. (1985). The traditional medical practitioner in Zimbabwe: His principles of practice and pharmacopoeia. Mambo Press, Gweru.

19. Gerstner, J. (1939). A preliminary checklist of Zulu names and plants with short notes. Bantu Stud. 13: 49-64.

20. Hegde, H.V., Hegde, G.R. and Kholkute, S.D. (2007). Herbal care for reproductive health: Ethno medicobotany from Uttara Kannada district in Karnataka, India. Complement. Ther. Clin. Pract. 13: 38-45.

21. Hossan, M.S., Hanif, A., Agarwala, B., Sarwar, M.S., Karim, M., Rahman, M.T.-U., Jahan, R. and Rahmatullah, M. (2010). Traditional use of medicinal plants in Bangladesh to treat urinary tract infections and sexually transmitted diseases. Ethnobot. Res. Appl. 8: 61-74.

22. Iwalewa, E.O., McGaw, L.J., Naidoo, V. and Eloff, J.N. (2007). Inflammation: The foundation of diseases and disorders. A review of phytomedicines of South African origin used to treat pain and inflammatory conditions. Afr. J. Biotechnol. 6: 28682885.

23. Jacot-Guillardmod, A. (1971). Flora of Lesotho. Verlag von J.Cramer, Lehre.

24. Jiofack, T., Ayissi, I., Fokunang, C., Guedje, N. and Kemeuze, V. (2009). Ethnobotany and phytomedicine of the upper Nyong valley forest in Cameroon. Afr. J. Pharm. Pharmacol. 3: 144-150.

25. Kale, R. (1995). South Africa's health: Traditional healers in South Africa: A parallel health care system. BMJ 310: 1182-1185.

26. Kamatenesi-Mugisha, M. and Oryem-Origa, H. (2005). Traditional herbal remedies used in the management of sexual impotence and erectile dysfunction in western Uganda. Afr. Health Sci. 5: 40-49.

27. Kandeel, F.R., Koussa, V.K.T. and Swerdloff, R.S. (2001). Male sexual function and its disorders: Physiology, pathophysiology, clinical investigation and treatment. Endocr. Reviews 22: 342-388.

28. Katende, A.B., Birnie, A. and Tengnäs, B.O. (1995). Useful trees and shrubs for Uganda, identification, propagation and management for agricultural and pastoral communities. Regional Soil Conservation Unit (RSCU), Nairobi.

29. Katsoulis, L.C., Veale, D.J. and Havlik, I. (2000). The pharmacological action of Rhoicissus tridentata on isolated rat uterus and ileum. Phytoth. Res. 14: 460-462.

30. King, R. and Homsy, J. (1997). Involving traditional healers in AIDS education and counseling in sub-Saharan Africa: a review. AIDS 11 (Suppl A): S217-225. 
31. Kloos, H. and McCullough, F.S. (1987). Plants with recognized molluscicidal activity. Mott, K.E (ed.), Plant molluscicides. John Willey and Sons Ltd, New York. Pp. 45-108.

32. Lans, C. (2007). Ethnomedicines used in Trinidad and Tobago for reproductive problems. J. Ethnobiol. Ethnomed. 3: 13 doi: 10.1186/1746-4269-3-13.

33. Lohiya, N.K., Manivannan, B., Mishra, P.K., Pathak, N., Sriram, S., Bhande, S.S. and Panneerdoss, S. (2002). Chloroform extract of Carica papaya seeds induces long-term reversible azoospermia in langur monkey. Asian J. Androl. 4: 17-26.

34. Mabogo, D.E.N. (1990). The ethnobotany of the VhaVenda. M.Sc Dissertation. University of Pretoria, Pretoria.

35. Marini-Bettolo, G.B., Nicoletti, M., Messana, I., Galeffi, C., Msonthi, J.D. and Chapya., W.A. (1985). Glucosides of Hypoxis nyasica Bak.: the structure of nyasoside, a new glucoside biologically related to hypoxoside. Tetrahed. 41: 665-670.

36. Mesfin, F., Demissew, S. and Teklehaymanot, T. (2009). An ethnobotanical study of medicinal plants in Wonago Woreda, SNNPR, Ethiopia. J. Ethnobiol. Ethnomed. 5: 28 doi:10.1186/1746-4269-5-28.

37. Meyer, J.J.M. and Afoloyan, A.J. (1995). Antibacterial activity of Helichrysum aureonitens (Asteraceae). J. Ethnopharmarcol. 47: 109-111.

38. Moeng, E.T. and Potgieter, M.J. 2011. The trade of medicinal plants by muthi shops and street vendors in the Limpopo Province, South Africa. J. Med. Plants Res. 5: 558-564.

39. Morton, J.F. (1987). Papaya. In: Morton, J. (ed.), Fruits of warm climates. Julia F. Morton, Miami ML. Pp. 336-346.

40. Msiska, R., Nangawe, E., Mulenga, D., Sichome, M., Kamanga, J. and Kwapa, P. (1997). Understanding lay perspectives: Care options for STD treatment in Lusaka, Zambia. Health Policy and Plan. 12: 248-252.

41. Mulaudzi, R.B., Ndhlala, A.R., Kulkarni, M.G., Finnie, J.F. and Van Staden, J. (2011). Antimicrobial properties and phenolic contents of medicinal plants used by the Venda people for conditions related to venereal diseases. J. Ethnopharmacol. 135: 330337.

42. Muthee, J.K., Gakuya, D.W., Mbaria, J.M., Kareru, P.G., Mulei, C.M. and Njonge, F.K. (2011). Ethnobotanical study of anthelmintic and other medicinal plants traditionally used in Loitoktok district of Kenya. J. Ethnopharmacol. 135: 15-21.

43. Muthu, C., Ayyanar, M., Raja, N. and Ignacimuthu, S. (2006). Medicinal plants used by traditional healers in Kancheepuram District of Tamil Nadu, India. J. Ethnobiol. Ethnomed. 2: 43 doi:10.1186/1746-4269-2-43.

44. Ndamba, J. and Chandiwana, S.K. (1986). The geographical variation in the molluscicidal potency of Phytolacca dodecandra (endo) berries in Zimbabwe. Trop. Geogr. Med. 40: 34-38.

45. Nel, G. (1914). Studien uber die Amaryllidaceae-Hypoxideae, unter besonder berucksichtigung der Afrikanischen arten. beitrage sur flora von Afrika. Bot. Jarb. System. Pl. Pfanz. 51: 334-338.

46. Rakuambo, N.C., Meyer, J.J., Hussein, A., Huyser, C., Mdlalose, S.P. and Raidani, T.G. (2006). In vitro effect of medicinal plants used to treat erectile dysfunction on smooth muscle relaxation and human sperm. J. Ethnopharmacol. 105: 84-88.

47. Richter, M.L. (2004). Traditional healing and human rights in South Africa. In: XV International AIDS Conference, Bangkok, 11-16 July (Abstract no.: MoPeE4200).

48. Samie, A., Obi, C.L., Bessong, P.O. and Namrita, L. (2005). Activity profiles of fourteen selected medicinal plants from rural Venda communities in South Africa against fifteen clinical bacterial species. Afr. J. Biotechnol. 4: 1443-1451.

49. Schmelzer, G.H. (2008). Euphorbia candelabrum Trémaux ex Kotschy. In: Schmelzer, G.H. and Gurib-Fakim, A. (eds.), Prota 11(1): Medicinal plants/Plantes médicinales. PROTA Foundation, [Internet] Record from PROTA4U (www.prota4u.org). [accessed 22 March 2012].

50. Schemelzer, H.H. and Gurib-Fakim, A. (2008). Plant resources of tropical Africa 11(1): Medicinal Plants 1. PROTA Foundation, Backurys Publishers, Leiden.

51. Seedat, Y.K. and Hitchcock, P.J. (1971). Acute renal failure from Callilepsis laureola. S. Afr. Med. J. 45: 832-833.

52. Semenya, S.S., Tshivikhawe, M.P. and Potgieter, M.J. 2012. Invasive alien plant species: A case study of their use in the Thulamela Local Municipality, Limpopo Province, South Africa. Sci. Res. Essays 7: 2363-2369.

53. Setswe, G. (1999). The role of traditional healers and primary health care in South Africa. Health SA Gesondheid 4: 56-60.

54. Steenkamp, V. (2003). Traditional herbal remedies used by South African women for gynaecological complaints. J. Ethnopharmacol. 86: 97-108.

55. Sumalatha, K., Kumar, S.A. and Lakshmi, S.M. (2010). Review on natural aphrodisiac potentials to treat sexual dysfunction. Int. J. Pharm. Ther. 1: 10-18.

56. Taniguchi, M., Chapya, A., Kubo, I. and Nakanishi, K. (1978). Screening of East African plants for antimicrobial activity. Chem. Pharmaceut. Bull. 26: 2910-2913.

57. Tene, V., Malagón, O., Finzi, P.V., Vidari, G., Armijos, C. and Zaragoza, T. (2007). An ethnobotanical survey of medicinal plants used in Loja and Zamora-Chinchipe, Ecuador. J. Ethnopharmacol. 111: 63-81.

58. Teng, Y., Guo, H., Liang, Z., Shu, Z., Li, Z. and Wu, W. (2011). Ethnobotanical survey of medicinal plants and their utilization in Shaanxi Province, China. J. Med. Pl. Res. 5: 1762-1778.

59. Treyvaud, V., Marston, A., Dyatmiko, W. and Hostettmann, K. (2000). Molluscicidal saponins from Phytolacca icosandra. Phytochem. 55: 603-609.

60. Tshisikhawe, N.P. (2002). Trade of indigenous medicinal plants in the Northern Province, Venda Region: their ethnobotanical importance and sustainable use. MSc. Dissertation. University of Venda for Science and Technology, Thohoyandou.

61. UNAIDS. (2006). Collaborating with traditional healers for HIV prevention and care in sub-Saharan Africa: Suggestions for programme managers and field workers. UNAIDS, Geneva.

62. Van Vuuren, S.F. (2007). The antimicrobial activity and essential oil composition of medicinal aromatic plants used in African traditional healing. PhD Thesis. University of the Witwatersrand, Johannesburg.

63. Veale, D.J.H., Furman, K.I. and Oliver, D.W. (1992). South African traditional herbal medicines used during pregnancy and childbirth. J. Ethnopharmacol. 36: 185-191.

64. Watt, J.M. and Breyer-Brandwijk, M.G. (1962). The medicinal and poisonous plants of south and eastern Africa. E. \& S. Livingstone Ltd., Edinburgh. 